\title{
PKM PAKAN RACIK ORGANIK DARI BUAH SERI
}

\author{
Akbar Habib ${ }^{1}$, Wan Arfiani Barus ${ }^{2}$,Wildani Lubis ${ }^{3}$ \\ 1)Program Studi Agribisnis Fakultas Pertanian Universitas Muhammadiyah Sumatera Utara, \\ 2)Program Studi Agroteknologi Fakultas Pertanian Universitas Muhammadiyah Sumatera Utara, \\ 3 Program Studi Agribisnis Universitas Muhammadiyah Sumatera Utara \\ akbarhabib@umsu.ac.id
}

\begin{abstract}
The Community Partnership Program entitled: "Organic Blended Pakan from Seri Fruit" aims to develop thinking skills and expertise that are economically independent; help create business fields to increase partner income. Partners in this PKM are chirping bird groups: Nirwana Bird Club and the Oversize Bird Club. The method used is to provide socialization and counseling to partners about the benefits of serial fruit and the importance of using organic feed for chirping birds and making organic concocted feed. The community partnership program is expected to be applied independently by partners to reduce chemical feed consumption, reduce expenditure on chemical feed purchases, and produce and market organic feed.
\end{abstract}

Keywords: Voer organic, Birdfeed, kerson fruits

\begin{abstract}
Abstrak
Program Kemitraan Masyarakat yang berjudul: 'Pakan Racik Organik dari Buah Seri' bertujuan untuk mengembangkan keterampilan berpikir dan keahlian yang mandiri secara ekonomi; membantu menciptakan lapangan usaha guna meningkatan pendapatan mitra. Mitra pada PKM ini adalah kelompok pencinta burung kicau yaitu : Nirwana Bird Club dan Oversize Bird Club. Metode yang digunakan yaitu dengan memberikan sosialisasi dan penyuluhan kepada mitra tentang manfaat buah seri serta pentingnya menggunakan pakan organik untuk burung kicau dan proses pembuatan pakan racik organik. Program kemitraan masyarakat diharapkan dapat diaplikasikan oleh mitra secara mandiri guna mengurangi konsumsi pakan kimia, mengurangi pengeluaran pembelian pakan kimia, mampu memproduksi dan memasarkan pakan racik organik.
\end{abstract}

Kata kunci: Voer organic, pakan burung, buah seri

\section{PENDAHULUAN}

Pada umumnya, burung
pengicau dipelihara hanya sebagai
hoby. Suara indah dan merdu yang
dihasilkan burung pengicau
memberikan suasana alami serta mampu
menghilangkan kepenatan atau
kejenuhan. Saat ini, pemeliharaan
burung kicau bukan hanya sebagai hoby
tetapi merupakan penggerak
perekonomian. Hal ini karena
perkembangan bisnis jual beli burung
pengicau, penangkaran, pakan ternak,
dan obat-obatan ternak.

Berkembangnya usaha budidaya burung kicau berdampak pada peningkatan permintaan pakan karena pakan merupakan kebutuhan primer bagi burung kicau maupun burung jenis lainnya. Untuk memenuhi ketersediaan pakan, dibutuhkan peningkatan produksi pakan yang memiliki nilai gizi tinggi. Untuk menghasilkan pakan yang berkualitas dibutuhkan komposisi dari bahan-bahan yang memiliki nilai gizi sesuai dengan kebutuhan burung. Kandungan gizi yang dibutuhkan burung kicau diperoleh dari sumber karbohidrat, protein, lemak, mineral dan 
vitamin. Kebutuhan vitamin diperoleh dari sayuran dan buah-buahan. Buah seri memiliki kandungan gizi yang dibutuhkan burung kicau serta mampu meningkatkan kualitas suara merdu yang dihasilkan burunng kicau.

Pohon seri merupakan tanaman liar yang tumbuh di alam terbuka dimana kegunaan pohon seri sebagai pelindung. Selama ini buah seri tidak dimanfaatkan dengan maksimal karena kurangnya pengatahuan akan manfaat dari kadungan gizi buah seri. Namun seiring berkembangnya zaman dan dilakukan berbagai penelitian ternyata kandungan gizi dari buah seri baik untuk kesehatan yang mampu mencegah berbagai penyakit yaitu: mencegah penyakit jantung, mengatasi tekanan darah tinggi, mencegah asam urat, diabetes, anemia dan lainnya (wikipedia.com).

Selain bermanfaat bagi kesehatan manusia, ternyata kandungan dari buah seri juga memiliki manfaat untuk burung pengicau.Pada umumnya burung pengicau merupakan jenis hewan pemakan jenis buah-buahan termasuk buah seri. Bau harum dan rasa manis dari buah seri menarik perhatian burung pengicau. Hal ini terlihat dari banyaknya burung bertengger di pohon seri dan menikmati buah seri. Kandungan dari buah seri mampu meningkatkan kualitas kicau burung.

Pada umumnya pakan burung yang diproduksi mengandung bahan kimia guna mencukupi gizi yang dibutuhkan burung karena minimnya pengetahuan tentang manfaat buah seri sebagai bahan pembuatan pakan.

Program Kemitraan Masyarakat yang dilakukan oleh tim pengusul yaitu melakukan proses pembuatan pakan racik organik yang berbahan baku buah seri dengan prosedur pembuatan pakan pada umumnya. Program Kemitraan Masyarakat yang dilaksanaka oleh tim pengusul berjudul :'Pakan Racik Organik dari Buah Seri'. Mitra pada PKM ini adalah kelompok pencinta burung kicau.

\section{METODE}

Metode yang digunakan pada Program Kemitraan Masyarakat adalah sosialisasi dan penyuluhan. Sosialisasi dan penyuluhan dilakukan pada mitra pecinta burung kicau yaitu: Nirwana Bird's Club dan Oversize Bird's Club. Mitra diberikan penjelasan mengenai manfaat dari buah seri bagi burung pengicau kemudian bagaimana pembuatan pakan racik organik dari buah seri.

Pembuatan pakan racik organik menggunakan bahan utama buah seri, dengan campuran bahan pendukung lainnya yaitu daging/ikan lele, ebi, kuning telur, tepung jagung tepung tapioka. Alat yang digunakan dalam proses pembuatan pakan racik organik yaitu alat penggiling daging (blender), pisau, saringan, ampia (alat pencetak pakan), timbangan, baskom, oven.

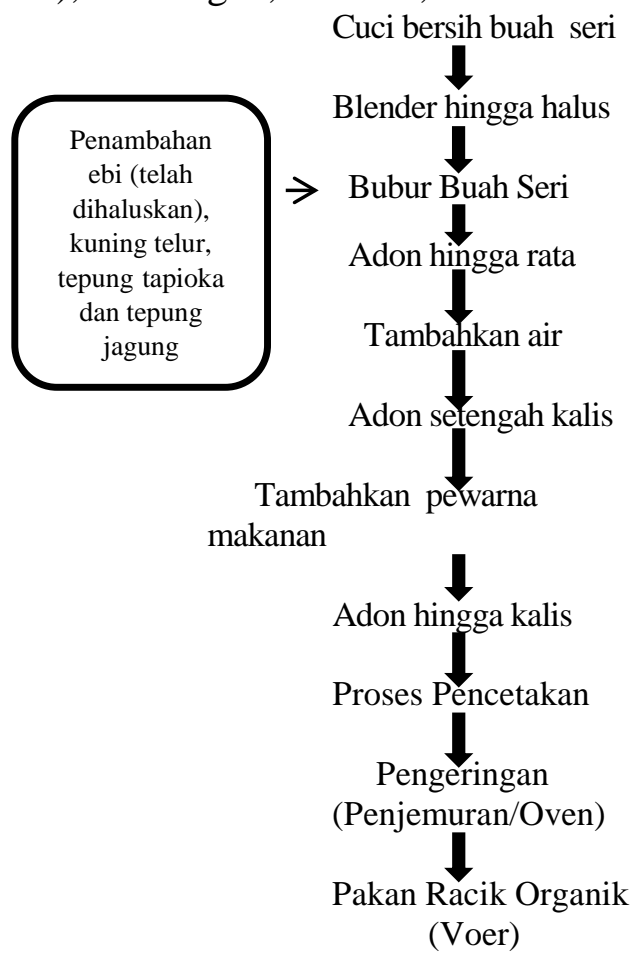


Akbar Habib, dkk. PKM Pakan Racik Organik Dari Buah Seri...

Gambar 1. Diagram Alir Pembuatan Pakan Racik Organik

\section{HASIL DAN PEMBAHASAN}

Program Kegiatan Masyarakat dilakukan pada mitra yang merupakan kelompok pencinta burung yang dikenal dengan Nirwana Bird's Club dan Oversize Bird's Club. Kedua mitra mendirikan club pecinta burung karena ingin menyalurkan hoby. Club yang didirikan mitra berada di Jalan Karya Jaya, Kelurahan Pangkalan Mansyur, Kecamatan Medan Johor.

Kegiatan dilaksanakan di lingkungan rumah salah satu anggota club yang bertempat di Jalan Karya Selamat, Kelurahan Pangkalan Mansyur, Kecamatan Medan Johor. Adapun kegiatan yang dilaksanakan meliputi :

\section{Rapat Tim PKM}

Tim PKM yang tediri dari 3 dosen Fakultas Pertanian Universitas Muhammadiyah Sumatera Utara melakukan rapat untuk membahas program yang akan dilaksanakan dengan mitra. Kegiatan PKM mengikutsertakan dua orang mahasiswa

\section{Sosialisasi/ penyuluhan}

Kegiatan PKM dilaksanakan pada hari Sabtu, 13 Juni 2020 di Jl. Karya Jaya, Pangkalan Mansyur, Medan Johor. PKM dihadiri oleh tim pengusul PKM, mitra yaitu kelompok Nirwana Bird Club dan Oversize Bird Club, beberapa orang dosen serta mahasiswa Fakultas Pertanian Universitas Muhammadiyah Sumatera Utara. Kegiatan dimulai pukul 10.00 Wib dirumah bapak Agus Suroso (anggota kelompok Nirwana Bird Club) dimana tim PKM melakukan perkenalan dengan mitra kelompok pecinta burung. Kemudian dilanjutkan dengan sosialisasi PKM yang disampaikan oleh ketua PKM yaitu bapak Akbar Habib, S.P., M.P tentang manfaat dari buah seri untuk burung kicau dan bagaimana proses pembuatan pakan racik organik dari buah seri.

\section{Pelatihan Pembuatan Pakan Racik}

Tim PKM memberikan pelatihan langsung kepada mitra dalam pembuatan pakan racik organik dari buah seri dengan mempergunakan bahan-bahan yang telah disediakan yaitu : buah seri, ebi, daging/ikan lele, kuning telur, tepung tapioka dan tepung jagung. Adapun proses pembuatan pakan racik organik dari buah seri dapat dilihat pada gambar 3 .

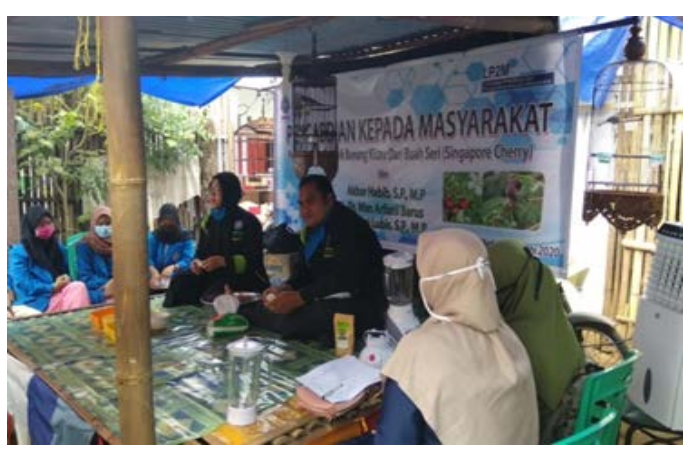

Gambar 2. Sosialisasi dan Penyuluhan

\section{a. Bahan-bahan}

bahan-bahan yang terdiri dari buah seri, ebi, dan daging di cuci bersih kemudian tiriskan. Sebelum dilakukan penghalusan (blender) daging di cincang halus guna mempermudah proses penghalusan.



Gambar 3. Bahan Pembuatan Pakan Racik Organik Buah seri 


\section{b. Penghalusan}

Haluskan bahan yaitu buah seri, ebi, dan daging secara terpisah. Buah seri yang telah dihaluskan kemudian disaring untuk memisahkan buah dengan ampas/kulit yang telah hancur.

\section{c. Pencampuran Bahan}

Ambil wadah untuk mencampurkan semua bahan yang telah dihaluskan seperti bubur buah seri, ebi dan daging yang telah dihaluskan campurkan, kemudian tambahkan tepung tapioka dan tepung jagung secara bertahap sambil tetap mengadon hingga semua tercampur merata. Tambahkan sedikit air jika diperlukan guna mempermudah proses pencampuran.

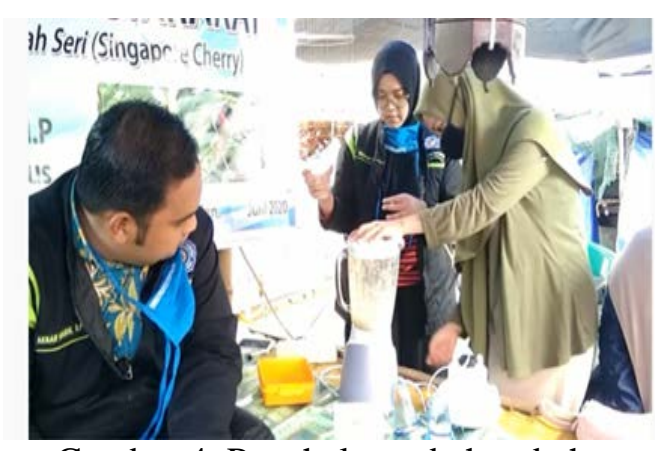

Gambar 4. Penghalusan bahan-bahan

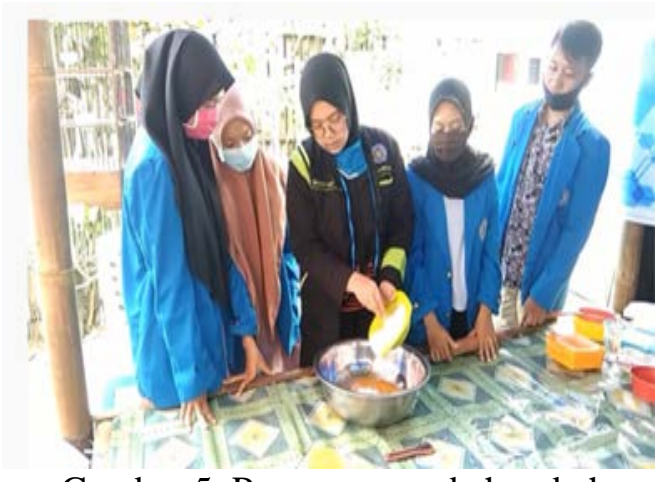

Gambar 5. Pencampuran bahan-bahan

\section{d. Penambahan Pewarna Makanan}

Saat adonan terasa setengah kalis, kemudian tambahkan sedikit pewarna makanan berwarna coklat susu yang telah dilarutkan dengan air secukupnya kedalam adonan. Campur hingga adonan merata dan menjadi kalis. Proses pengadonan hingga kalis membutuhkan waktu lebih kurang 30 menit.

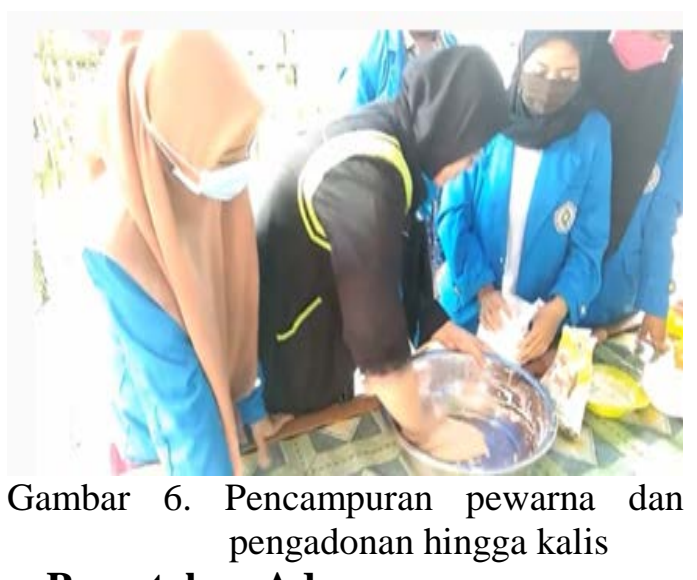

\section{e. Pencetakan Adonan}

Adonan yang telah kalis kemudian dibagi menjadi beberapa bagian, kemudian dibentuk bulatan (seperti bola) kemudian pipihkan dengan menggunan roll (pemipih adonan) tujuannya untuk mempermudah dalam pencentakan voer. Langkah selanjutnya ambil alat pencetak voer kemudian masukan adonan yang telah dipipihkan untuk dicetak.

\section{f. Pengeringan Adonan}

Hasil adonan yang telah selesai di cetak kemudian disusun di wadah untuk dikeringkan. Proses pengeringan dapat dilakukan secara manual maupun menggunakan alat. Jika dilakukan secara manual, adonan dijemur dibawah terik matahari hingga kering. Proses pengeringan ini membutuhkan waktu cukup lama karena tergantung pada cuaca. Jika pengeringan dilakukan dengan menggunakan oven membutuhkan waktu 30-45 menit.

Adonan yang telah selesai di bakar (proses pengeringan) kemudian letakan di wadah untuk didinginkan. Setelah itu, adonan dapat diaplikasikan pada burung. Pengaplikasian dapat berbentuk serbuk yang diberikan pada burung atau berbentuk pakan pada umumnya. Jika pakan ingin diberikan 
Akbar Habib, dkk. PKM Pakan Racik Organik Dari Buah Seri...

dalam berbentuk serbuk, maka setelah adonan dingin kemudian dutumbuk hingga berbentuk serbuk.

\section{SIMPULAN}

Diharapkan kedua mitra untuk terus mengaplikasikan pakan racik organik dari buah seri untuk menjaga gizi dengan memberikan makanan yang mengandung protein tinggi sehingga burung akan menhasilkan suara yang merdu dan mengurangi biaya penggunaan pakan kimia dan juga mengembangkan produksi pakan racik organik dari buah seri sehigga dapat menambah pemasukan mitra.

Hasil dari sosialisasi dan penyuluhan yang dilakukan tim PKM akan di publikasikan pada jurnal pengabdian serta merupakan salah satu Tri Dharma Perguruan Tinggi yang telah dilakukan oleh dosen Fakultas Pertanian Univrsitas Muhammadiyah Sumatera Utara.

\section{DAFTAR PUSTAKA}

Afandi R, Siregar MR, Sari DI, Savira $\mathrm{N}$, Wulantiya S, Habib A. 2019. Financial Feasibility Analysis Of Voerseri Business (Packing Bird Feed from Kersen/Singapore Cherry). Journal of Agribusiness Sciences. 2 (2) : 42-46

Habib A., Afandi R, Siregar MR. 2019. Analysis of the Voerseri Business Feasibility Study (a Packaged Bird Feed from Singapore Cherry). Journal of Agricultureand Veterinary Science. 2(1) : 53-59

J. Daryatno, Widiarso BP. 2015. Manfaat Nutrisi Bagi Performa Burung Kicau. Sekolah Tinggi Penyuluhan Pertanian Magelang

Setya. 2020. Pakan Buah Untuk Burung Kacer Agar Lebih Sehat. https://rajakicau.com/2020/07/ 05/pakan-buah-untuk-burungkecer-agar-lebih-sehat/

Widodo W. 2015. Formulasi Pakan Burung Ocehan dan Hias. Jakarta:. PenebarSwadaya 